\title{
ASSESSMENT OF PERIOPERATIVE PREDICTORS OF DIFFICULT LAPAROSCOPIC CHOLECYSTECTOMY
}

\author{
By

\section{Abd El-Rahman Fathy El-sayed Darwish, Abduh Mohamed El-Banna and Abdoh Salem}

\author{
Department of General Surgery, Faculty of Medicine, Al-Azhar University
}

Corresponding author: Abd El -Rahman Fathy El-sayed Darwish,

Mobile: 01027766523, E-mail: abdelrahmandarwish9090@gmail.com

\begin{abstract}
Background: Laparoscopic cholecystectomy (LC) is considerably performed world over. The entire number of patients suffering serious complications is noticeably high in spite of its low incidence rate, referring it a "rare but frequent" problem. Perioperative prediction of "difficult Laparoscopic cholecystectomy (LC) and operative grading system may not only improve patient safety but also be beneficial in lessening the overall cost of therapy and it may aid a surgeon in the decisive, most convenient approach (open /laparoscopic) for a particular patient, and advocating the patient about it, in that way, reducing the morbidity, complication.

Objective: To identify the pre-operative indicators for difficult laparoscopic cholecystectomy, identify the intra- operative indicators for difficult laparoscopic cholecystectomy, and develop predictive scoring system based on these factors.

Patients and methods: The present study was conducted over 50 patients aged between 23 to 59 years who underwent a laparoscopic cholecystectomy at Al-hussien Hospital and Bab-Alsharia Hospital of Al-Azhar University during the period of research from January 2020 to August 2020. Detailed clinical history was obtained that included demographic data consisting of age, sex and obesity, history of previous hospitalization for acute cholecystitis, history of endoscopic retrograde cholangiopancreatography (ERCP) and comorbid diseases (diabetes, or elevated liver enzymes etc). Diagnosis of cholelithiasis was confirmed in patients presenting with abdominal symptoms using an abdominal ultrasonography (USG).
\end{abstract}

Results: Two (4\%) of cases were found to have been falling in the age group (20-30) years, 20 (40\%) of them were falling in the age group (31-40), 22(44\%) had an age ranged between (41-50) years, whereas 6 $(12 \%)$ of patients were in the age group 51-60 years The mean age was $41.82 \pm 7.65$ years. In this current work age wasn't found to be correlated with difficult operation. Regarding gender and BMI, the majority of included cases, 33 (66\%), were females with the mean body mass index was $29.8 \pm 5.129$ and gender was not linked to difficult Laparoscopic cholecystectomy (LC) The net outcome of the present work showed that 33 (66\%) cases had easy operation. Furthermore, 14 (28\%) patients had difficult laparoscopic cholecystectomy and $3(6 \%)$ were found to be very difficult on laparoscopic cholecystectomy. ROC curve analysis showed that a score above 4.5 was found to be associated with difficult cholecystectomy. As the score increases, difficulty level increases with sensitivity (50\%) and specificity (93.9\%) and AUROC curve 0.749; P= (0.007).

Conclusion: The difficult laparoscopic cholecystectomy and conversion to open surgery can be predicted preoperatively based on number of previous attacks of cholecystitis, gall bladder wall thickness, and presence or absence of pericholecystic collection and palpable gall bladder and/or impacted stones.

Keywords: Perioperative predictors of difficult, Laparoscopic cholecystectomy. 


\section{INTRODUCTION}

Cholelithiasis is the most popular biliary illness and one of the extremely common causes of abdominal pain as it is present in $10-15 \%$ of the overall individuals. Though it is asymptomatic in most of them (>80\%), virtually, $1-2 \%$ of asymptomatic patients will develop symptoms necessitating cholecystectomy annually, making cholecystectomy the furthermost common operation performed by general surgeons (Abd-El-Aal and Abdallah, 2018 and Bustos et al., 2019).

Conventional open cholecystectomy (OC) has been dramatically switched to laparoscopic cholecystectomy (LC) since its inception in 1987 (Hu et al., 2017).

Laparoscopic cholecystectomy has promptly become the gold standard for monotonous gall bladder removal. Management of biliary tract disease has evolved from being a major procedure to a minimal invasiveness surgery concomitant with less pain relatively, safe tolerable day care procedure today, and earlier yield to full activity (Vivek et al., 2014). Likewise, the superiority of early LC over delayed LC was established in the treatment of acute cholecystitis (AC) (Inoue et al., 2017).

Laparoscopic cholecystectomy though safe and effective, it is deemed to be one of the most problematical laparoscopic surgery performed by surgeons worldwide as various problems may be encountered as difficulty in creating pneumoperitoneum, accessing peritoneal cavity, and releasing adhesions (Vivek et al., 2014).

Also, surgeons often face difficulties in performing LC due to their inability to precisely identify the anatomy of Calot's triangle as a result of severe inflammation. Therefore, in patients with severe acute cholicystities (AC) the rate of complications, such as bile leakage, common bile duct injury, and bowel injury, is high after LC, suggesting the importance of evaluation of inflammation severity (Inoue et al., 2017).

Furthermore, current literature suggests that the rate of intra-operative conversion from $\mathrm{LC}$ to $\mathrm{OC}$ is $1 \%-15 \%$ and that conversion is known to increase perioperative time, complication rates, perioperative costs, the length of hospital stay, and hospital charges. Conversion is also associated with complications including death, bile duct injury, bile leak, or bleeding, requiring reoperation or transfusion (Hu et al., 2017).

Thus, difficult laparoscopic cholecystectomy (DLC) is a primal problem which surgeons may encounter when treating AC. Precise prediction of DLC can help surgeons to prepare for perioperative challenges, optimize surgical procedures and reduce the postoperative complications. However, there are just a few scoring systems to assess the risk of LC to convert to open cholecystectomy for AC, but they offer no effective prediction of DLC (Wu et al., 2019).

Factors affecting the outcomes of LC have been heavily investigated over the past years. There are various pre or intraoperative factors that make $\mathrm{LC}$ a technically difficult procedure. These include acute cholecystitis, empyema gall bladder, gangrenous cholecystitis, fibrosed gallbladder, severe adhesions in calot $^{\text {ee }}$ triangle and intrahepatic gall 
bladder. These problems are difficult to assess preoperatively but are usually encountered during LC and therefore responsible for major difficulty in performing the surgery (Ghanem et al., 2017). Hence, operative grading system for laparoscopic cholecystectomy and scoring system "Operative classifications" was proposed classify the difficult Cholecystectomy from mild to extreme on the basis of intraoperative predicators (Ahmed et al., 2018).

The present study aimed to identify the pre-operative indicators for difficult laparoscopic cholecystectomy, identify the intra- operative indicators for difficult laparoscopic cholecystectomy, and develop predictive scoring system based on these factors.

\section{PATIENTS AND METHODS}

This study was a prospective study that was conducted at Al-hussien and Bab Elsherria Hosptal of Al-Azhar University on a total of 50 patients who underwent laparoscopic cholecystectomy during the period from January 2020 to August 2020.

Inclusion criteria: Cases of acute or chronic cholecystitis with cholelithiasis who uunderwent laparoscopic cholecystectomy with informed consent for operative intervention during the research period.

\section{Exclusion criteria:}

The following were excluded from the study:

- Age below 18 years.

- Laparoscopic cholecystectomy performed with other laparoscopic intervention in the same setting.
- Laparoscopic cholecystectomy with Common Bile Duct (CBD) exploration.

- Viral marker positive patients (HBs Ag, HCV, HIV).

- Pregnancy.

- Patients with common bile duct (CBD) calculus, dilated CBD, features of obstructive jaundice.

- Patients who refused laparoscopic cholecystectomy.

- Patients who were not fit for general anesthesia due to various medical illnesses.

- Patient who didn't give informed consent.

- Contraindications to Laparoscopic cholecystectomy like: Cardiovascular and pulmonary disease, coagulopathies and end-stage liver disease (ESLD).

Ethical approval: The study was approved by the local ethics committee of the Ethical Committee of Faculty of Medicine, AL-Azhar University. An informed consent was taken from each individual participated in the present study after thorough explanation of the purpose and procedure of the study. Any participating patient had the right to withdraw from the study without being adversely impacted regarding the medical service he received.

Screening for patients with cholelithiasis presenting with abdominal symptoms, upper abdominal pain, or vomiting or dyspepsia or jaundice were done using an abdominal ultrasonography.

\section{Eligible patients were subjected to:}

- Thorough history taking including duration of illness, history of 
endoscopic

cholangiopancreatography

retrograde

(ERCP), and previous history of acute cholecystitis.

- Abdominal examination and liver examination including liver span and presence or absence of ascites or splenomegaly, presence of palpable gall bladder.

- Presence of previous abdominal scar.

\section{Anthropometric measurements:}

Assessment of patients' weight, height then BMI was calculated using the formula: BMI weight $(\mathrm{kg}) /[\text { height }(\mathrm{m})]^{2}$.
Routine preoperative investigations including CBC, liver and kidney function tests, coagulation profile, biochemical investigations and Abdominal Ultrasonography.

\section{Statistical Analysis:}

In the present study, statistical analyses of data were carried out using SPSS version 23. Numerical data were expressed as mean \pm standard deviation. Qualitative variables were assessed by Chi square and Fisher exact test. $\mathrm{P}$ value < 0.05 was considered significant.

\section{RESULTS}

The present study was conducted over 50 patients aged between 23 to 59 years who underwent a laparoscopic cholecystectomy At (Al-hussien and Bab Elsherria) of Al-Azhar University during the period of research from January 2020 to August 2020. Detailed clinical history was obtained that included demographic data consisting of age, sex and obesity, history of previous hospitalization for acute cholecystitis, history of ERCP and comorbid diseases (diabetes,or elevated liver enzymes etc). Diagnosis of cholelithiasis was confirmed in patients presenting with abdominal symptoms using an abdominal ultrasonography (USG) (Table 1).

Table (1): Demographic data of studied cases

\begin{tabular}{|c|c|}
\hline Mean \pm SD & Patients $(\mathbf{N}=\mathbf{5 0})$ \\
\hline Age (years) & $41.82 \pm 7.65$ \\
\hline Gender (Male/ Female) & $17 / 33$ \\
Percentage of male $(\boldsymbol{\%})$ & $34 \%$ \\
\hline Body Mass index $\left(\mathbf{B M I ) ~}\left(\mathbf{k g} / \mathbf{m}^{\mathbf{2}}\right)\right.$ & $29.8 \pm 5.129$ \\
\hline
\end{tabular}


Out of 50 patients included in this study 9 patients had dense adhesions in the Calot's triangle $<50 \%$ and 2 patients had adhesion burying the gall bladder. Also, $4(8.3 \%)$ cases had distended gall bladder, 6(12.5\%) cases suffered from stone $\geq 1 \mathrm{~cm}$ impacted in Hartman's pouch, eight patients had difficulty in access to peritoneal cavity. Injury in bile duct was happened in 7 patients. In addition, one patient had pus outside gallbladder, 3 had pus collection, and nine patients had more $120 \mathrm{~min}$ to identify cystic artery. Laparoscopic cholecystectomy surgery consumed 60-120 min in 14 patients, and more than $120 \mathrm{~min}$ in three patients. Out of 50 patients, 10 patients had spilled stones, 11 patients had cystic artery injury, and 3 cases were converted to open cholecystectomy (Table 2).

Table (2): Intra-operative parameters among studied cases

\begin{tabular}{|l|c|c|}
\hline \multicolumn{1}{|c|}{ Value } & Frequency & Percent \\
\hline Appearance & 39 & \\
No adhesion & 9 & $78 \%$ \\
Adhesion <50\% & 2 & $18 \%$ \\
Adhesion burying the gall bladder & 35 & \\
\hline GB (contraction/ distention) & 4 & $72.9 \%$ \\
No & 6 & $8.3 \%$ \\
Distended & 3 & $12.5 \%$ \\
Stone $\geq 1$ cm impacted in Hartman's pouch & $6.3 \%$ \\
Unable to grasp with atraumatic laproscopic forceps & & \\
\hline Access to peritoneal cavity & 42 & $84 \%$ \\
No & 8 & $16 \%$ \\
Adhesion pervious surgery limiting access & & \\
\hline Complications & 7 & $14 \%$ \\
Bile injury & 1 & $2 \%$ \\
Pus outside GB & 3 & $6 \%$ \\
Pus collection & & \\
\hline Time taken for surgery & 33 & $66 \%$ \\
$<60$ nim & 14 & $28 \%$ \\
60-120 min & 3 & $6 \%$ \\
\hline 120 min & 11 & $22 \%$ \\
\hline Cystic artery injury & 3 & $6 \%$ \\
\hline Conversion to open & & \\
\hline
\end{tabular}

Thirty three $(66 \%)$ cases had easy operation. Furthermore, 14 (28\%) patients had difficult laparoscopic cholecystectomy and $3(6 \%)$ were found to be very difficult on laparoscopic cholecystectomy (Table 3).

Table (3): Outcome of the operation among studied cases.

\begin{tabular}{|l|c|c|}
\hline & Frequency & Percent \\
\hline Surgical outcome & 33 & \\
Easy & 14 & $66 \%$ \\
Difficult & 3 & $28 \%$ \\
Very difficult & $6 \%$ \\
\hline
\end{tabular}


Pre-operative, and USG findings against the endpoint of difficult cholecystectomy:

The present study showed that among 4 patients with history of acute cholecystitis, 3 patients had difficult extraction of GB without statistical significant $(\mathrm{p}=0.091)$.

In addition, 2 out of 33 cases $(6.1 \%)$ with easy outcome had history of ERCP, whereas 1 out of 13 patients with difficult outcome had history of ERCP. There was no statistically significant difference between history of ERCP and outcome of operation $(\mathrm{P}=0.894)$.

Moreover out of 14 patients with difficult outcome, four $(28.6 \%)$ had history of DM while 14 out of 33 cases with easy outcome and one of 3 patients with very difficult outcome had history of DM. Furthermore, there was no statistically significant difference between distention of CBD and outcome of operation $(\mathrm{P}=0.263)$.

This study showed that pericholecystic collection was significantly association with difficult laparoscopic cholecystectomy $(\mathrm{P}=0.004)$ as 4 cases with pericholecystic collection had difficult cholecystectomy and one case had very difficult outcome.

In our study palpable GB was significantly associated with difficult cholecystectomy $(\mathrm{P}=0.028)$. Two out of 33 who fall in easy cholecystectomy category $(6.1 \%)$ had palpable GB, 5 out of 14 cases in difficult cholecystectomy category $(35.7 \%)$ had palpable GB, and 1 out of three cases $(33.3 \%)$ of very difficult cholecystectomy category had palpable GB.

Also, impacted stone on ultrasonography found associated with difficulty of cholecystectomy in present study $(\mathrm{P}=0.004)$. However, other factors including GB wall thickness, GB stone size, GB stone number, and liver ultrasonography finding found insignificant with the cholecystectomy outcome in present study $(\mathrm{P}>0.05)$ (Table 4). 
Table (4): Pre-operative, and USG findings against the endpoint of difficult cholecystectomy

\begin{tabular}{|c|c|c|c|c|}
\hline $\begin{array}{ll}\text { Parameters } & \text { Outcome } \\
\end{array}$ & $\begin{array}{l}\text { Easy } \\
\mathrm{N}=33\end{array}$ & $\begin{array}{c}\text { Difficult } \\
\mathrm{N}=14\end{array}$ & $\begin{array}{c}\text { Very difficult } \\
\mathrm{N}=3\end{array}$ & P-value \\
\hline $\begin{array}{c}\text { History of acute } \\
\text { cholecystitis } \\
\text { No } \\
\text { Yes }\end{array}$ & $\begin{array}{c}32(97 \%) \\
1(3 \%)\end{array}$ & $\begin{array}{c}11(78.6 \%) \\
3(21.4 \%)\end{array}$ & $\begin{array}{c}3(100 \%) \\
0(0 \%)\end{array}$ & 0.091 \\
\hline $\begin{array}{c}\text { History of ERCP } \\
\text { No } \\
\text { Yes }\end{array}$ & $\begin{array}{c}31(93.9 \%) \\
2(6.1 \%)\end{array}$ & $\begin{array}{c}13(92.9 \%) \\
1(7.1 \%)\end{array}$ & $\begin{array}{c}3(100 \%) \\
0(0 \%)\end{array}$ & 0.894 \\
\hline $\begin{array}{c}\text { History of DM } \\
\text { No } \\
\text { Yes } \\
\end{array}$ & $\begin{array}{l}19(57.6 \%) \\
14(42.4 \%)\end{array}$ & $\begin{array}{c}10(71.4 \%) \\
4(28.6 \%)\end{array}$ & $\begin{array}{l}2(66.7 \%) \\
1(33.3 \%)\end{array}$ & 0.660 \\
\hline $\begin{array}{c}\text { Abdominal scar } \\
\text { No } \\
\text { Infra-umbilical } \\
\text { Supra-umbilical } \\
\end{array}$ & $\begin{array}{c}27(81.8 \%) \\
3(9.1 \%) \\
3(9.1 \%)\end{array}$ & $\begin{array}{c}10(71.4 \%) \\
3(21.4 \%) \\
1(7.1 \%)\end{array}$ & $\begin{array}{c}2(66.7 \%) \\
0(0 \%) \\
1(33.3 \%)\end{array}$ & 0.464 \\
\hline $\begin{array}{c}\text { CBD distension } \\
\text { Normal } \\
\text { Distended }\end{array}$ & $\begin{array}{c}31(93.9 \%) \\
2(6.1 \%)\end{array}$ & $\begin{array}{l}12(85.7 \%) \\
2(14.3 \%)\end{array}$ & $\begin{array}{l}2(66.7 \%) \\
1(33.3 \%)\end{array}$ & 0.263 \\
\hline $\begin{array}{c}\text { Pericholecystic collection } \\
\text { No } \\
\text { Yes }\end{array}$ & $\begin{array}{c}33(100 \%) \\
0(0 \%)\end{array}$ & $\begin{array}{c}10(71.4 \%) \\
4(28.6 \%)\end{array}$ & $\begin{array}{l}2(66.7 \%) \\
1(33.3 \%)\end{array}$ & $0.004^{*}$ \\
\hline $\begin{array}{c}\text { Palpable GB } \\
\text { No } \\
\text { Yes }\end{array}$ & $\begin{array}{l}31(93.9 \%) \\
2(6.1 \%)\end{array}$ & $\begin{array}{l}9(64.3 \%) \\
5(35.7 \%)\end{array}$ & $\begin{array}{l}2(66.7 \%) \\
1(33.3 \%)\end{array}$ & $0.028^{*}$ \\
\hline $\begin{array}{c}\text { GB Wall thickness } \\
<4 \mathrm{~mm} \\
\geq 4 \mathrm{~mm}\end{array}$ & $\begin{array}{c}31(93.9 \%) \\
2(6.1 \%)\end{array}$ & $\begin{array}{c}10(71.4 \%) \\
4(28.6 \%)\end{array}$ & $\begin{array}{l}2(66.7 \%) \\
1(33.3 \%)\end{array}$ & 0.077 \\
\hline $\begin{array}{c}\text { GB stone size } \\
\text { small } \\
\text { Large }\end{array}$ & $\begin{array}{l}27(81.8 \%) \\
6(18.2 \%)\end{array}$ & $\begin{array}{l}8(57.1 \%) \\
6(42.9 \%)\end{array}$ & $\begin{array}{c}3(100 \%) \\
0(0 \%)\end{array}$ & 0.117 \\
\hline $\begin{array}{c}\text { GB stone number } \\
\text { Solitary } \\
\text { Multiple }\end{array}$ & $\begin{array}{l}7(21.2 \%) \\
26(78.8 \%)\end{array}$ & $\begin{array}{l}5(35.7 \%) \\
9(64.3 \%)\end{array}$ & $\begin{array}{l}1(33.3 \%) \\
2(66.7 \%)\end{array}$ & 0.559 \\
\hline $\begin{array}{c}\text { Impacted stone in the } \\
\text { neck of GB } \\
\text { No } \\
\text { Yes }\end{array}$ & $\begin{array}{c}33(100 \%) \\
0(0 \%)\end{array}$ & $\begin{array}{c}10(71.4 \%) \\
4(28.6 \%)\end{array}$ & $\begin{array}{l}2(66.7 \%) \\
1(33.3 \%)\end{array}$ & $0.004^{* *}$ \\
\hline $\begin{array}{c}\text { Liver ultrasonography } \\
\text { finding } \\
\text { Average } \\
\text { Fatty }\end{array}$ & $\begin{array}{c}30(90.9 \%) \\
3(9.1 \%)\end{array}$ & $\begin{array}{c}11(78.6 \%) \\
3(21.4 \%)\end{array}$ & $\begin{array}{c}3(100 \%) \\
0(0 \%)\end{array}$ & 0.396 \\
\hline
\end{tabular}


Pre-operative and USG against conversion to open:

There was no significant association between Pre-operative and intraoperative

data and the conversion to open surgery ( $\mathrm{P}>0.05)$ (Table 5).

Table (5): Pre-operative and intraoperative findings against the conversion to open surgery

\begin{tabular}{|c|c|c|c|}
\hline $\begin{array}{ll}\text { Carameters } & \text { Conversion to open } \\
\end{array}$ & $\operatorname{No}(N=47)$ & Yes $(\mathrm{N}=3)$ & P-value \\
\hline $\begin{array}{l}\text { History of acute cholecystitis } \\
\text { No } \\
\text { Yes }\end{array}$ & $\begin{array}{c}43(91.5 \%) \\
4(8.5 \%)\end{array}$ & $\begin{array}{c}3(100 \%) \\
0(0 \%)\end{array}$ & 0.598 \\
\hline $\begin{array}{l}\text { History of ERCP } \\
\text { No } \\
\text { Yes }\end{array}$ & $\begin{array}{c}44(93.6 \%) \\
3(6.4 \%)\end{array}$ & $\begin{array}{c}3(100 \%) \\
0(0 \%)\end{array}$ & 0.652 \\
\hline $\begin{array}{l}\text { History of DM } \\
\text { No } \\
\text { Yes } \\
\end{array}$ & $\begin{array}{l}29(61.7 \%) \\
18(38.3 \%)\end{array}$ & $\begin{array}{l}2(66.7 \%) \\
1(33.3 \%)\end{array}$ & 0.863 \\
\hline $\begin{array}{l}\text { Abdominal scar } \\
\text { No } \\
\text { Infra-umbilical } \\
\text { Supra-umbilical }\end{array}$ & $\begin{array}{c}37(78.7 \%) \\
6(12.8 \%) \\
4(8.5 \%)\end{array}$ & $\begin{array}{c}2(66.7 \%) \\
0(0 \%) \\
1(33.3 \%)\end{array}$ & 0.337 \\
\hline $\begin{array}{l}\text { CBD distension } \\
\text { Normal } \\
\text { Distended }\end{array}$ & $\begin{array}{c}43(91.5 \%) \\
4(8.5 \%)\end{array}$ & $\begin{array}{l}2(66.7 \%) \\
1(33.3 \%)\end{array}$ & 0.164 \\
\hline $\begin{array}{l}\text { Pericholecystic collection } \\
\text { No } \\
\text { Yes }\end{array}$ & $\begin{array}{c}43(91.5 \%) \\
4(8.5 \%)\end{array}$ & $\begin{array}{l}2(66.7 \%) \\
1(33.3 \%)\end{array}$ & 0.164 \\
\hline $\begin{array}{l}\text { Palpable GB } \\
\text { No } \\
\text { Yes }\end{array}$ & $\begin{array}{c}40(85.1 \%) \\
7(14.9 \%)\end{array}$ & $\begin{array}{l}2(66.7 \%) \\
1(33.3 \%)\end{array}$ & 0.398 \\
\hline $\begin{array}{l}\text { GB Wall thickness } \\
<4 \mathrm{~mm} \\
\geq 4 \mathrm{~mm}\end{array}$ & $\begin{array}{l}41(87.2 \%) \\
6(12.8 \%)\end{array}$ & $\begin{array}{l}2(66.7 \%) \\
1(33.3 \%)\end{array}$ & 0.396 \\
\hline $\begin{array}{l}\text { GB stone size } \\
\text { small } \\
\text { Large }\end{array}$ & $\begin{array}{l}35(74.5 \%) \\
12(25.5 \%)\end{array}$ & $\begin{array}{c}3(100 \%) \\
0(0 \%)\end{array}$ & 0.315 \\
\hline $\begin{array}{l}\text { GB stone number } \\
\text { Solitary } \\
\text { Multiple }\end{array}$ & $\begin{array}{l}12(25.5 \%) \\
35(74.5 \%)\end{array}$ & $\begin{array}{l}1(33.3 \%) \\
2(66.7 \%)\end{array}$ & 0.765 \\
\hline $\begin{array}{l}\text { Impacted stone in the neck of GB } \\
\text { No } \\
\text { yes }\end{array}$ & $\begin{array}{c}43(91.5 \%) \\
4(8.5 \%)\end{array}$ & $\begin{array}{l}2(66.7 \%) \\
1(33.3 \%)\end{array}$ & 0.165 \\
\hline $\begin{array}{l}\text { Liver ultrasonography finding } \\
\text { Average } \\
\text { Fatty }\end{array}$ & $\begin{array}{c}41(87.2 \%) \\
6(12.8 \%)\end{array}$ & $\begin{array}{c}3(100 \%) \\
0(0 \%)\end{array}$ & 0.373 \\
\hline
\end{tabular}

Pre-operative, and USG findings and the risk of difficult cholecystectomy:

Patients with pericholecystic collection had 3.750 times more risk for difficult cholecystectomy when compared with patients with no pericholecystic collection with significant $p$ value $=0.003$. Patients who had palpable gall bladder had 8.455 
times more risk for difficult cholecystectomy when compared with patients without; with significant $\mathrm{p}$ value $=0.013$. Patients who had gall bladder wall thickness $\geq 4 \mathrm{~mm}$ had 6.458 times more risk for difficult cholecystectomy when compared with patients with gall bladder wall thickness $<4 \mathrm{~mm}$; with significant $\mathrm{p}$ value $=0.037$. Patients who had impacted stone in the neck of GB had 3.750 times more risk for difficult cholecystectomy when compared with patients without impacted stone with significant $\mathrm{p}$ value $=0.003$. All the other variables were not statistically significant ( $\mathrm{p}$-value $>0.05$ ) (Table 6).

Table (6): Pre-operative, and USG findings and risk of difficult cholecystectomy

\begin{tabular}{|c|c|c|c|c|}
\hline $\begin{array}{ll}\text { Risk of difficult } \\
\text { Parameters }\end{array}$ & $\begin{array}{c}\text { Difficult } \\
(\mathrm{N}=17)\end{array}$ & $\begin{array}{c}\text { Easy } \\
(\mathbf{N}=33)\end{array}$ & $\begin{array}{l}\text { Odd ratio } \\
\text { (C.I) }\end{array}$ & P-value \\
\hline $\begin{array}{l}\text { Age } \\
>40 \text { years } \\
\leq 40 \text { years }\end{array}$ & $\begin{array}{c}12(70.6 \%) \\
5(29.4 \%)\end{array}$ & $\begin{array}{l}16(48.5 \%) \\
17(51.5 \%)\end{array}$ & $\begin{array}{c}2.550 \\
(0.733-8.872)\end{array}$ & 0.136 \\
\hline $\begin{array}{l}\text { BMI } \\
>25 \mathrm{~kg} / \mathrm{m}^{2} \\
\leq 25 \mathrm{~kg} / \mathrm{m}^{2}\end{array}$ & $\begin{array}{c}13(76.5 \%) \\
4(23.5 \%)\end{array}$ & $\begin{array}{l}20(60.6 \%) \\
13(39.4 \%)\end{array}$ & $\begin{array}{c}2.875 \\
(0.616-3.539)\end{array}$ & 0.266 \\
\hline $\begin{array}{l}\text { History of acute cholecystitis } \\
\text { Yes } \\
\text { No }\end{array}$ & $\begin{array}{c}3(17.6 \%) \\
14(82.4 \%)\end{array}$ & $\begin{array}{c}1(3 \%) \\
32(97 \%)\end{array}$ & $\begin{array}{c}6.857 \\
(0.655-71.807)\end{array}$ & 0.711 \\
\hline $\begin{array}{l}\text { History of ERCP } \\
\text { Yes } \\
\text { No }\end{array}$ & $\begin{array}{c}1(5.9 \%) \\
16(94.1 \%)\end{array}$ & $\begin{array}{c}2(6.1 \%) \\
31(93.9 \%)\end{array}$ & $\begin{array}{c}0.969 \\
(0.082-11.512)\end{array}$ & 0.980 \\
\hline $\begin{array}{l}\text { History of DM } \\
\text { Yes } \\
\text { No }\end{array}$ & $\begin{array}{c}5(29.4 \%) \\
12(70.6 \%)\end{array}$ & $\begin{array}{l}14(42.4 \%) \\
19(57.6 \%)\end{array}$ & $\begin{array}{c}0.565 \\
(0.162-1.976)\end{array}$ & 0.369 \\
\hline $\begin{array}{l}\text { Abdominal scar } \\
\text { Present } \\
\text { Absent }\end{array}$ & $\begin{array}{c}5(29.4 \%) \\
12(70.6 \%) \\
\end{array}$ & $\begin{array}{c}6(18.2 \%) \\
27(81.8 \%) \\
\end{array}$ & $\begin{array}{c}1.875 \\
(0.477-7.363) \\
\end{array}$ & 0.364 \\
\hline $\begin{array}{l}\text { CBD distension } \\
\text { Distended Normal }\end{array}$ & $\begin{array}{c}3(17.6 \%) \\
14(82.4 \%)\end{array}$ & $\begin{array}{c}2(6.1 \%) \\
31(93.9 \%)\end{array}$ & $\begin{array}{c}3.321 \\
(0.498-22.146)\end{array}$ & 0.196 \\
\hline $\begin{array}{l}\text { Pericholecystic collection } \\
\text { Yes } \\
\text { No }\end{array}$ & $\begin{array}{c}5(29.4 \%) \\
12(70.6 \%)\end{array}$ & $\begin{array}{c}0(0 \%) \\
33(100 \%)\end{array}$ & $\begin{array}{c}3.750 \\
(2.310-6.088) \\
\end{array}$ & $<0.001^{* *}$ \\
\hline $\begin{array}{l}\text { Palpable GB } \\
\text { Yes } \\
\text { No }\end{array}$ & $\begin{array}{c}6(35.3 \%) \\
11(64.7 \%)\end{array}$ & $\begin{array}{c}2(6.1 \%) \\
31(93.9 \%) \\
\end{array}$ & $\begin{array}{c}8.455 \\
(1.481-48.259)\end{array}$ & $<0.008 *$ \\
\hline $\begin{array}{l}\text { GB Wall thickness } \\
\geq 4 \mathrm{~mm}<4 \mathrm{~mm}\end{array}$ & $\begin{array}{c}5(29.4 \%) \\
12(70.6 \%)\end{array}$ & $\begin{array}{c}2(6.1 \%) \\
31(93.9 \%) \\
\end{array}$ & $\begin{array}{c}6.458 \\
(1.100-37.918) \\
\end{array}$ & $0.024 *$ \\
\hline $\begin{array}{l}\text { GB stone size } \\
\text { Large } \\
\text { Small }\end{array}$ & $\begin{array}{c}6(35.3 \%) \\
11(64.7 \%) \\
\end{array}$ & $\begin{array}{c}6(18.2 \%) \\
27(81.8 \%) \\
\end{array}$ & $\begin{array}{c}2.455 \\
(0.648-9.292) \\
\end{array}$ & 0.180 \\
\hline $\begin{array}{l}\text { GB stone number } \\
\text { Multiple } \\
\text { Solitary }\end{array}$ & $\begin{array}{c}11(64.7 \%) \\
6(35.3 \%)\end{array}$ & $\begin{array}{c}26(78.8 \%) \\
7(21.2 \%)\end{array}$ & $\begin{array}{c}0.494 \\
(0.135-1.808)\end{array}$ & 0.282 \\
\hline $\begin{array}{l}\text { Impacted stone in the neck of GB } \\
\text { yes } \\
\text { No }\end{array}$ & $\begin{array}{l}5(29.4 \%) \\
12(70.6 \%)\end{array}$ & $\begin{array}{c}0(0 \%) \\
33(100 \%)\end{array}$ & $\begin{array}{c}3.750 \\
(2.310-6.088)\end{array}$ & 0.001 \\
\hline $\begin{array}{l}\text { Liver ultrasonography } \\
\text { Fatty } \\
\text { Average }\end{array}$ & $\begin{array}{c}3(17.6 \%) \\
14(82.4 \%)\end{array}$ & $\begin{array}{c}3(9.1 \%) \\
30(90.9 \%)\end{array}$ & $\begin{array}{c}2.143 \\
(0.383-11.984)\end{array}$ & 0.398 \\
\hline
\end{tabular}


Correlation of peri operative score and the outcome:

Among the $33(100 \%)$ cases with easy operation, $31(93,9 \%)$ had an easy score while $2(6,1 \%)$ had difficult one.. Also, among the $14(100 \%)$ cases with difficult operation, $9(64.3 \%)$ cases had an easy score, 4 cases $(28.6 \%)$ had difficult score while $1 \quad(7.1 \%)$ had very difficult operation. And the only 3 cases who developed very difficult operation: one case $(33.3 \%)$ had very difficult score and another $2(66.7 \%)$ cases had difficult operation (Table 7).

Table (7): Correlation of preoperative score and the outcome

\begin{tabular}{|l|c|c|c|c|}
\hline Surgical outcome & Easy & difficult & $\begin{array}{c}\text { Very } \\
\text { difficult }\end{array}$ & Total \\
\hline Score: & & & & \\
Easy(0-5) & $31(93.9 \%)$ & $9(64.3 \%)$ & $2(66.7 \%)$ & $\mathbf{4 2}(\mathbf{8 4} \%)$ \\
Difficult(6-10) & $2(6.1 \%)$ & $4(28.6 \%)$ & $1(33.3 \%)$ & $\mathbf{7 ( 1 4 \% )}$ \\
Very difficult(11-15) & $0(0 \%)$ & $1(7.1 \%)$ & $0(0 \%)$ & $\mathbf{1 ( 2 \% )}$ \\
\hline Total & $\mathbf{3 3 ( 1 0 0 \% )}$ & $\mathbf{1 4}(\mathbf{1 0 0 \% )}$ & $\mathbf{3}(\mathbf{1 0 0 \%})$ & $\mathbf{5 0 ( 1 0 0 \% )}$ \\
\hline P-value & \multicolumn{5}{|c|}{$\mathbf{0 . 0 8 7}$} \\
\hline
\end{tabular}

Roc curve analysis showed that a score above 4.5 was found to be associated with difficult cholecystectomy. As the score increases, difficulty level increases with sensitivity $(50 \%)$ and specificity $(93.9 \%)$ and AUROC curve 0.749; $\mathrm{P}=(0.007)$.

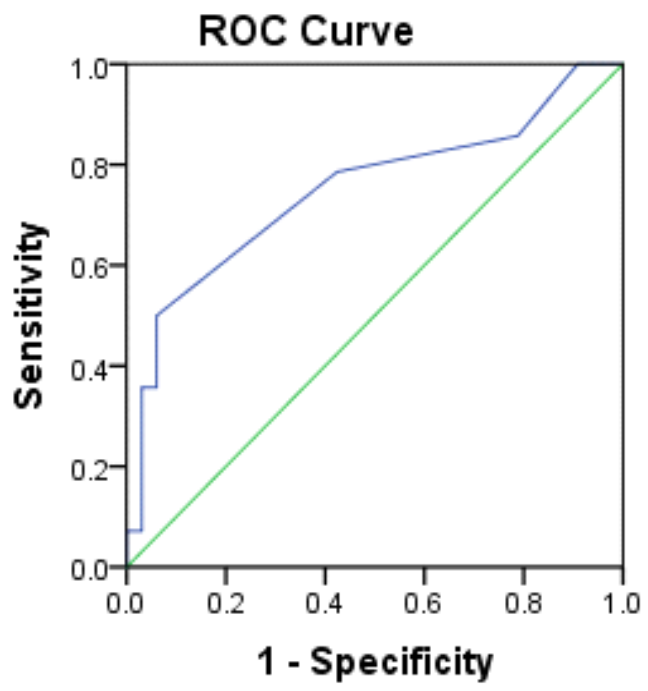

Diagonal segments are produced by ties.

Figure (1): ROC curve analysis of score in predicting difficult laparoscopic cholecystectomy

\section{DISCUSSION}

As regard age, results of the present work revealed that $2(4 \%)$ of cases were found to have been falling in the age group (20-30) years, 20 (40\%) of them were falling in the age group (31-40), $22(44 \%)$ had an age ranged between (41$50)$ years, whereas $6(12 \%)$ of patients were in the age group 51-60 years The mean age was $41.82 \pm 7.65$ years. In this 
current work age wasn't found to be correlated with difficult operation.

In accordance to our results, Agrawal et al. (2015) found that the majority of patients were in the age group of $\leq 50$ years (25 patients) and only $16.7 \%$ (five cases) were $>50$ years and they found no significant correlation between age and the difficult level of surgery.

Moreover, in line with our results, Abd-El-Aal and Abdallah (2018) found that the mean age of cases underwent LC was 43.92 years (range: 19-70 years). Most patients were in the age group of 41-50 years followed by age group of 3140 years. Also, Kulkarni and Kumar (2018) found that the maximum incidence (36.14\%) of LC was seen in the age group of 35 to 50 years.

However, in accordance to our results, Sandhu et al. (2016) published that there was no significant association was found between age and outcome of LC and that was in conformity with Naik and Kailas (2017) who found that age was not a significant $(\mathrm{p}=1.59)$ factor for predicting difficulty in LC.

A meta-analysis by Rothman et al. (2016) in their meta-analysis concluded that quality of evidence for age as a risk factor for conversion was low.

Regarding gender and BMI, the majority of included cases, were females with the gender was not linked to difficult LC.

In studies done worldwide, male sex has been described to be associated with difficult LC (O'Leary et al., 2013). In contrary to our finding, Ghanem and his co-workers (2017) also found that the patient gender was found to be a significant factor that associates the difficulty of LC.

Agrawal et al. (2015) found that there was no statistically significant difference in the total time taken for the procedure between the two sexes.

In conformity with our results, Bhar et al. (2013) published a study suggesting that male sex was not statistically significant predictor of difficult LC. This finding was also in line with that of Nityasha et al. (2016) and Naik and Kailas (2017) who published that gender had little influence on the course of surgery which may be due to small size of their sample.

Meta-analysis by Rothman et al. (2016) found that quality of evidence of male gender as a risk factor for conversion was low.

Moreover, out of 14 patients with difficult outcome, $28.6 \%$ had history of DM. Furthermore, there was no statistically significant difference between distention of CBD and outcome of operation.

Our results were in accordance to meta-analysis of Rothman et al. (2016) published that none of studies evaluating diabetes mellitus as a risk factor found it to be significant. Lowndes et al. (2016) mentioned that diabetes was not statistically significant in this regression model as predictors of prolonged operative duration.

On the other hand, history of diabetes mellitus (DM) was found to be a significant predictive factor for difficulties during LC in a published studies by Bhar et al. (2013) and Ghanem et al. (2017) as they claimed that diabetes had positive 
correlation with difficulties encountered in LC as in diabetic patients there may be several attacks of sub-acute inflammation causing more scarring and making cholecystectomy more difficult.

In addition, this study showed that pericholecystic collection was significantly association with difficult laparoscopic cholecystectomy. On risk factor assessment, patients with pericholecystic collection had 3.750 times more risk for difficult cholecystectomy when compared with patients with no pericholecystic collection with significant.

In agreement with our results, $\mathrm{Abd}-\mathrm{El}$ Aal and Abdallah (2018) mentioned that pericholecystic collection, and GB wall thickness was found to be predictor of difficult LC. In thier study, 28 patients had palpable GB, 14 of them had a difficult procedure after surgery. Palpable GB was found to be statistically significant in univariate analysis of preoperative and intraoperative outcomes with risk factor.

There was a statistical significant association between pericholecystic collection on Sonography and LC difficulty in other studies (Agrawal et al., 2016, Sandhu et al., 2016 and Ghanem et al., 2017).

However, Naik and Kailas (2017) found that pericholecystic collection was not statistically significant in predicting difficulty.

Clinically palpable GB may be due to distended GB, mucocele of GB, thickwalled or owing to adhesions between the GB and the omentum. Increased thickness of GB wall was associated with difficult dissection of the GB from its bed; thick
GB wall may make grasping and manipulation of GB difficult, and this also makes the dissection at Calot's triangle and the GB bed to be difficult and limits the extent of anatomical definition (Lowndes et al., 2016).

Sugrue et al. (2015) published palpable gallbladder has been shown to increase the likelihood of a difficult procedure and in conformity Kumar et al. (2015) found it to be significant clinical predictive factor in LC. Agrawal et al. (2016) mentioned that clinically palpable GB was found to be predictor of difficult LC. Singh and Nath (2016) published that if gall bladder is palpable then it would be difficult, as there may be residual inflammation adhesion. Elhady and Esmail (2017) found that presence of palpable tender right hypochondrial mass was risk factor for difficulty, complications, operative and postoperative outcome in patients undergoing LC for acute cholecystitis.

Also, in the current work, impacted stone on ultrasonography found associated with difficulty of cholecystectomy in present study. Patients who had impacted stone in the neck of GB had 3.750 times more risk for difficult cholecystectomy when compared with patients without impacted stone.

In line with that, Kidwai et al. (2016) concluded that impacted stones at Hartmann's pouch make dissection difficult because of difficulty in holding GB at Hartmann's pouch. Husain et al. (2016) found that stone size more than 1 $\mathrm{cm}$ was a significant factor for difficult and very difficult LC with. Moreover, Ghanem et al. (2017); found that it was a significant predictive factor for difficult LC. 
Patients who had gall bladder wall thickness $\geq 4 \mathrm{~mm}$ had 6.458 times more risk for difficult cholecystectomy when compared with patients with gall bladder wall thickness $<4 \mathrm{~mm}$.

Agrawal et al. (2016) found that increased GB wall thickness is associated with difficult dissection of the GB from its bed. Nityasha et al. (2016) found in their study that thickened gall bladder wall was found significant predictor of difficulty and was significantly associated with adhesions bleeding increased operating time and all the three converted patients had thickened gall bladder wall. Naik and Kailas (2017) published that significantly intraoperative difficulty demonstrated in patients with GB wall thickness greater than $3 \mathrm{~mm}$ that may be due to difficulty during grasping the gall bladder, difficult GB bed dissection and higher incidence of bleeding.

Presence of a thick GB wall may make grasping and manipulation of GB difficult. This makes the dissection at the Calot's triangle and the GB bed to be difficult and limits the extent of anatomical definition. In our study, we found no significant correlation between the GB wall thickness and the difficulty level of surgery. Better randomization of the patients into the two groups and a larger sample size would have allowed us to extrapolate the results into the general population (Agrawal et al., 2015).

Furthermore, Kania (2017) recommended that it should be borne in mind that ultrasound assessment of the gall-bladder wall, even if no pathology has been found, remains an auxiliary examination and does not mean that the operator should not be watchful and thoughtful while skeletonizing the Calot"s triangle structures.

In this study also, other factors as GB stone size, GB stone number, and liver ultrasonography findings were found insignificant with the cholecystectomy outcome in the present study.

Several prediction models for a difficult LC, based on subjective assessment intra-operative difficulty have been proposed (e.g. 'unable to', 'difficult dissection of'). However, these assessments also depend on surgeons' experience and routine practice and are therefore not easily transferable between institutions (Wennmacker et al., 2019).

History of previous abdominal scar was found to be insignificant predictive factor for difficulty during LC. This was in agreement with Bhar et al. (2013) as they did not find any significant correlation between past abdominal surgeries and difficulties encountered during LC which also was is in accordance with the study of Kumar et al. (2015) as they were published that previous surgery was not significant predictive risk factor for difficult LC. Sandhu et al. (2016) also found that the abdominal scar in has not been a significant association with the outcome of LC. Ko-iam and his colleuges (2017) found that it was non-significant predictive Factors for a long hospital stay in patients undergoing LC.

However, Singh and Nath (2016) found that previous abdominal scar (supraumbilical) will lead to conversion to open cholecystectomy in conformity to Agrawal et al. (2016) and Ghanem et al. (2017) who published those upper 
abdominal scars was found to be statistically significant factor.

The scoring system used in this study was of Randhawa and Pujahari (2010) the scores were added up to get a total score and the patients were divided into categories of risks based on the total score, Results of recurrent study revealed that among $100 \%$ cases with easy operation, positive predictive value for this scoring system was $93.9 \%$ as they were predicted to be easy. Also, among $100 \%$ cases with difficult operation, $64.3 \%$ cases had an easy score, $28.6 \%$ had difficult score while $7.1 \%$ had very difficult operation.

Agrawal et al. (2015) utilized the same score observed a positive predictive value of $76.4 \%$ for cases predicted to be easy. For cases predicted to be difficult, they registered a positive predictive value of $100 \%$ for the scoring system.

Abd-El-Aal and Abdallah (2018) found that the number of cases predicted to be difficult/very difficult on preoperative evaluation were $28 \%$ patients, of which $26 \%$ were difficult/very difficult on surgery, whereas $2 \%$ cases were turned out to be easy. The cases predicted to be easy on preoperative evaluation were $72 \%$, of which $63 \%$ cases were actually easy whereas $9 \%$ cases turned out to be difficult/very difficult on surgery, and also five cases were converted to open.

Moreover, Roc curve analysis in our study showed that a score above 4.5 was found to be associated with difficult cholecystectomy. As the score increases, difficulty level increases with sensitivity (50\%) and specificity (93.9\%) and AUROC curve 0.749 .
In agreement with our results, $A b d-E l$ Aal and Abdallah (2018) found that ROC curve for difficult versus easy cases at cutoff point greater than 5 and AUC of 0.91 , with $95 \% \mathrm{CI}=0.83-0.96$, showed sensitivity of 77.8 , specificity $96.9 \%$.

The sensitivity and specificity used in a study conducted by Veerank and Togale (2018) at score 5, were $86.36 \%$ and $75 \%$, respectively and the prediction has come true in $90.48 \%$ easy and $66.67 \%$ difficult cases.

A similar study conducted by Gupta and his Co-workers (2013) on this scoring method had sensitivity and specificity of $95.74 \%$ and $73.68 \%$, respectively with positive predictive values for easy and difficult as $90 \%$ and $88 \%$, respectively.

So, from these results, we observed that the preoperative scoring system is statistically and clinically a good and valuable for predicting the perioperative outcome in LC. Also, we conclude that the difficult laparoscopic cholecystectomy and conversion to open surgery can be predicted preoperatively based on number of previous attacks of cholecystitis, gall bladder wall thickness, and presence of pericholecystic collection, palpable gall bladder and or impacted stones.

Tackling these problems depend on the experience and learning curve of the surgeon. It is a well-accepted fact that an experienced surgeon needs less operating time and is better equipped to face these risk factors. It must be understood that none of these risk factors are an absolute contraindication to proceed with the procedure. But while assessment of a patient these must be kept in mind so that intraoperative technical difficulty can be expected and averted. 


\section{CONCLUSION}

The difficult laparoscopic cholecystectomy and conversion to open surgery can be predicted preoperatively based on number of previous attacks of cholecystitis, gall bladder wall thickness, and presence or absence of pericholecystic collection and palpable gall bladder /or impacted stones.

\section{REFERENCES}

1. Abd-El-Aal AS and Abdallah HA. (2018): Evaluation of preoperative predictive factors for difficult laparoscopic cholecystectomy in comparison with intraoperative parameters. The Egyptian Journal of Surgery, 37(4):504511.

2. Agrawal N, Singh S and Khichy S. (2015): Preoperative prediction of difficult laparoscopic cholecystectomy: a scoring method. Nigerian Journal of Surgery, 21(2):130-133.

3. Ahmed N, ul Hassan M, Tahira M, Samad A and Rana HN. (2018): Intra-Operative Predictors of difficult cholecystectomy and Conversion to Open Cholecystectomy-A New Scoring System. Pakistan Journal of Medical Sciences, 34(1):62-66.

4. Bhar P, Halder SK, Ray RP and Bhattacharjee PK. (2013): Preoperative prediction of difficult laparoscopic Cholecystectomy. Indian Medical Gazette, 128-133.

5. Bustos BI, Pérez-Palma E, Buch S, Azócar L, Riveras E, Ugarte GD, Toliat M, Nürnberg $\mathbf{P}$, Lieb W, Franke $A$ and Hinz $S$. (2019): Variants in ABCG8 and TRAF3 genes confer risk for gallstone disease in admixed Latinos with Mapuche Native American ancestry. Scientific Reports, 9(1):1-12.

6. Elhady HA and Esmail TA. (2017): Is C reactive protein an Independent Risk Factor for Complication of Laparoscopic Cholecystectomy for Acute Cholecystitis. Journal of Surgery, 5(3-1):16-22.

7. Ghanem YB, Fahmy KS and Refaat DO. (2017): Preoperative prediction of difficult laparoscopic cholecystectomy: in Zagazig university hospitals. Zagazig University Medical Journal, 23(4):208-220.

8. Gupta N, Ranjan G, Arora M, Goswami B, Chaudhary $P$ and Kapur A. (2013): Validation of a scoring system to predict difficult laparoscopic cholecystectomy. International Journal of Surgery, 11:10021006.

9. Hu AS, Menon R, Gunnarsson $R$ and De Costa A. (2017): Risk factors for conversion of laparoscopic cholecystectomy to open surgeryA systematic literature review of 30 studies. The American Journal of Surgery, 214(5):920930.

10. Husain A, Pathak S and Firdaus H. (2016): Assessment of operative predictors for difficulty in laproscopic cholecystectomy. International Journal of Contemporary Medical Research, 3(4):1232-1234.

11. Inoue K, Ueno T, Douchi D, Shima K, Goto S, Takahashi M, Morikawa T, Naitoh T, Shibata C and Naito H. (2017): Risk factors for difficulty of laparoscopic cholecystectomy in grade II acute cholecystitis according to the Tokyo guidelines 2013. BMC Surgery, 17(1):114-121.

12. Kania D.: Ultrasound measurement of the gallbladder wall thickness in the assessment of the risk of conversion from elective laparoscopic cholecystectomy to open surgery-olkusz county experience. Polish Journal of Surgery, 88(6):334-345.

13. Kidwai R, Pandit $R$, Issrani $R$ and Prabhu N. (2016): Assessment of Risk Factors for Conversion from Difficult Laparoscopic to Open Cholecystectomy-A Hospital Based Prospective Study. Journal of Krishna Institute of Medical Sciences (JKIMSU), 5(3):84-97.

14. Ko-Iam W, Sandhu T, Paiboonworachat S, Pongchairerks P, Chotirosniramit A, Chotirosniramit N, Chandacham K, Jirapongcharoenlap $\mathbf{T}$ and Junrungsee $\mathbf{S}$. (2017): Predictive factors for a long hospital stay in patients undergoing laparoscopic cholecystectomy. International Journal of Hepatology, 17:1-8. 
15. Kulkarni SV and Kumar SS. (2018): Preoperative predictors of a difficult laparoscopic cholecystectomy. International Surgery Journal, 5(2):608-613.

16. Kumar P, Pankaj A and Bhushan R. (2015): Predicting difficulities in Laparoscopic Cholecystectomy using clinical, laboratory and ultrasonological criteria: A prospective study. Journal of Evidence Based Medicine and Healthcare, 2(43):7667-7672.

17. Lowndes B, Thiels CA, Habermann EB, Bingener J, Hallbeck $S$ and Yu D. (2016): Impact of patient factors on operative duration during laparoscopic cholecystectomy: evaluation from the National Surgical Quality Improvement Program database. The American Journal of Surgery, 212(2):289-296.

18. Naik C and Kailas CT. (2016): Predicting difficulty in laparoscopic cholecystectomy by clinical, hematological and radiological evaluation. International Surgery Journal, 4(1):189-193.

19. Nityasha, Dalal S, Sharma V, Saharan A and Bakshi V. (2016): Evaluation of predictive factors for conversion of laparoscopic cholecystectomy. International Journal of Enhanced Research in Medicines \& Dental Care, 3:7-10.

20. O'Leary DP, Myers E, Waldron $D$ and Coffey JC. (2013): Beware the contracted gallbladder - Ultrasonic predictors of conversion. Surgeon, 11:187-190.

21. Randhawa JS and Pujahari AK. (2010): Preoperative prediction of difficult lap chole: a scoring method. Indian Journal of Surgery, 71(4):198-201

22. Rothman PJ, Burcharth J, Pommergaard HC, Viereck $S$ and Rosenberg J. (2016): Preoperative risk factors for conversion of laparoscopic cholecystectomy to open surgery: a systematic review and meta-analysis of observational studies. Digestive Surgery, 33(5):414-423.

23. Sandhu G, Rana ML and Singh K. (2016): Preoperative prediction of difficult laparoscopic cholecystectomy: A scoring method. Indian Journal of Applied Research. 6(6):1-6.

24. Singh AK and Nath U. (2016): Predictor of difficult Laparoscopic Cholecystectomy. Indian Journal of Applied Research, 6(3):619-623.

25. Sugrue M, Sahebally SM, Ansaloni L and Zielinski MD. (2015): Grading operative findings at laparoscopic cholecystectomy-a new scoring system. World Journal of Emergency Surgery, 10(1):14-21.

26. Veerank $\mathrm{N}$ and Togale MD. (2018): Validation Of A Scoring System To Predict Difficult Laparoscopic Cholecystectomy: A One-Year Cross-Sectional Study. Journal of the West African College of Surgeons, 8(1):23-39.

27. Vivek MA, Augustine AJ and Rao R. (2014): A comprehensive predictive scoring method for difficult laparoscopic cholecystectomy. Journal of Minimal Access Surgery, 10(2):6267.

28. Wennmacker SZ, Bhimani N, van Dijk AH, Hugh TJ and de Reuver PR. (2018): Predicting operative difficulty of laparoscopic cholecystectomy in patients with acute biliary presentations. ANZ Journal of Surgery, 89(11):1451-1456.

29. Wu T, Luo M, Guo Y, Bi J, Guo Y and Bao S. (2019): Role of procalcitonin as a predictor in difficult laparoscopic cholecystectomy for acute cholecystitis case: A retrospective study based on the TG18 criteria. Scientific Reports, 9(1):1-7. 
تقييم العو امل المحيطة للتنبؤ بصعوبه استثئصال المراره

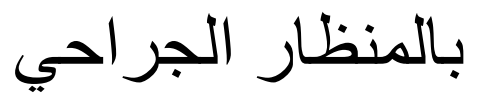

عبد الرحمن فتحي السيد محمد درويش, عبده محمد البنا, عبده عبدالله سالم قسم الجراحة العامة, كلية الطب، جامعة الأزهر

E-mail: abdelrahmandarwish9090@gmail.com

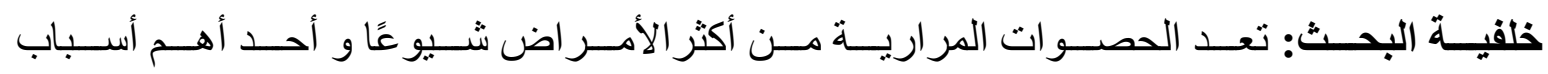

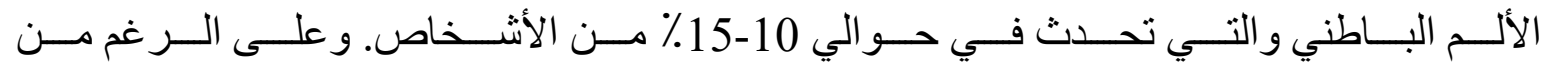

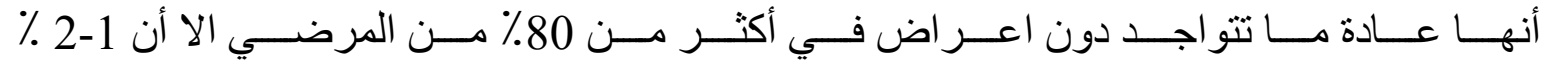

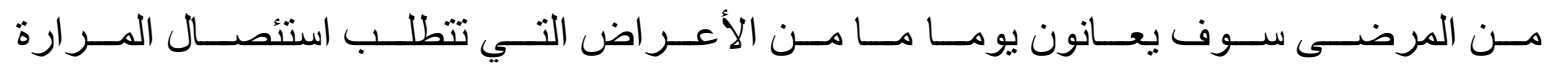

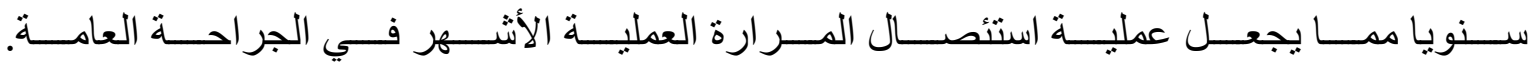

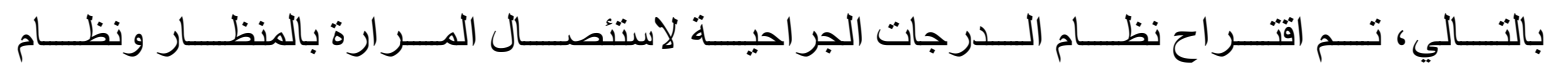

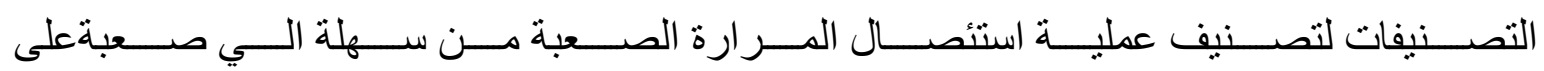
أساس عو امل للتنبؤ اما قبل العملية أو أثناء العملية.

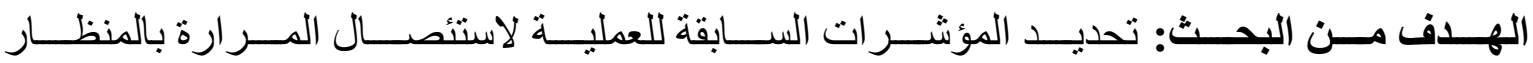

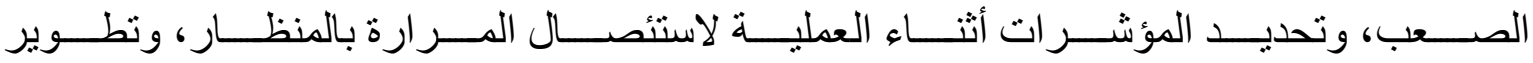
نظام التسجيل التنبؤي بناءً على هذه العو امل.

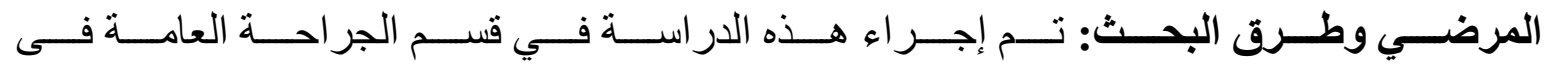

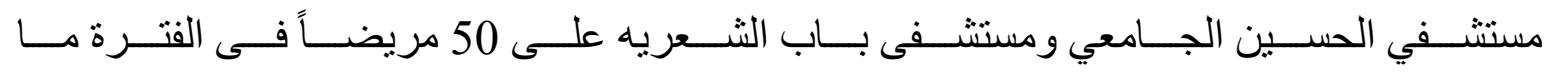

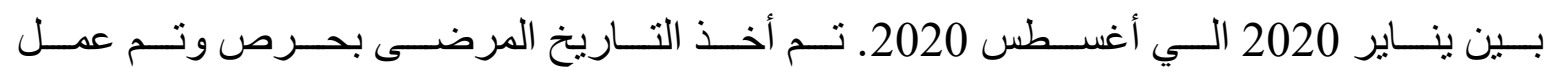

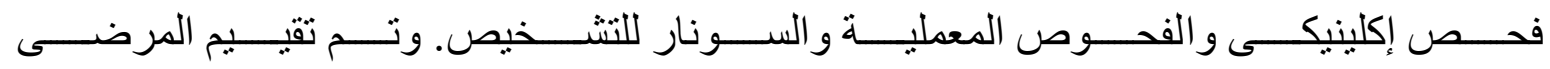
المختارين لعو امل الخطر قبل الجر احة.

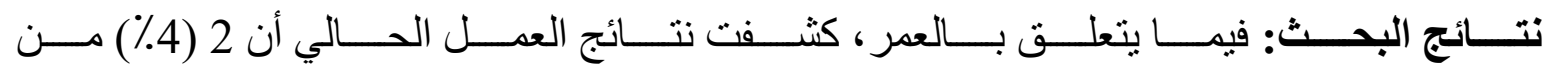

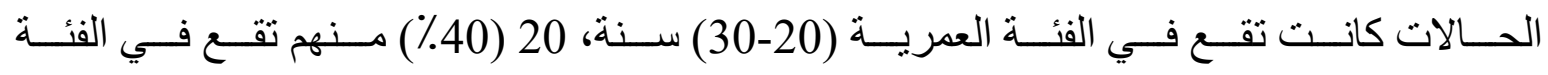

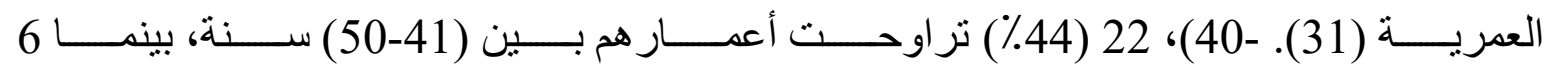

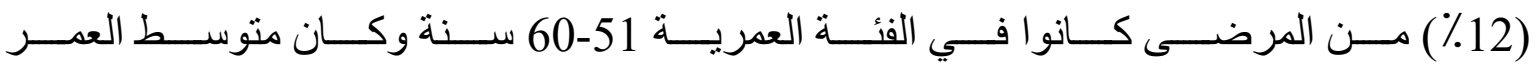

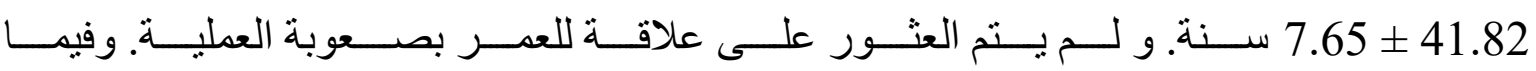




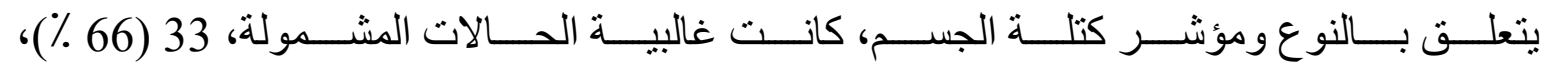

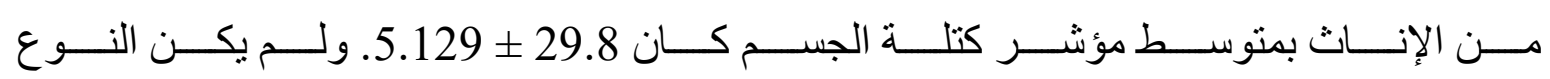

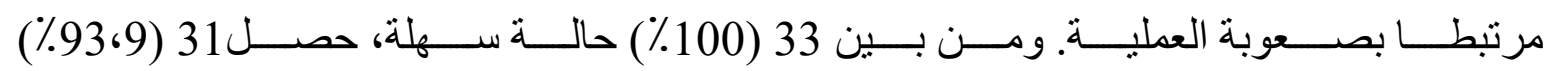

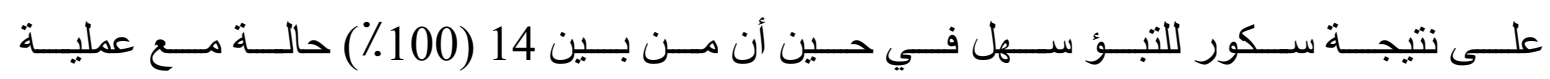

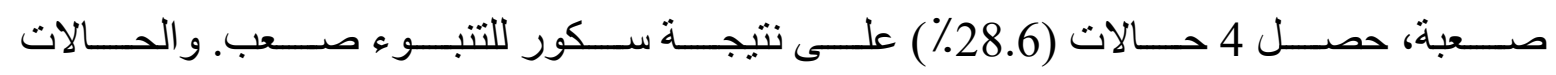

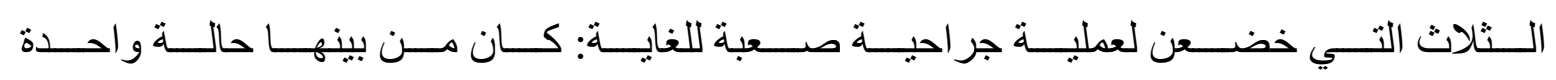

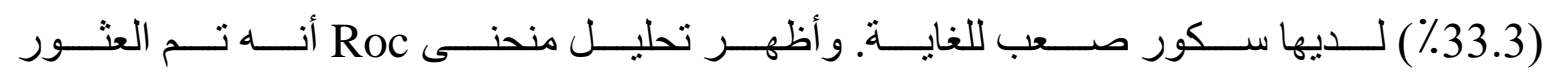

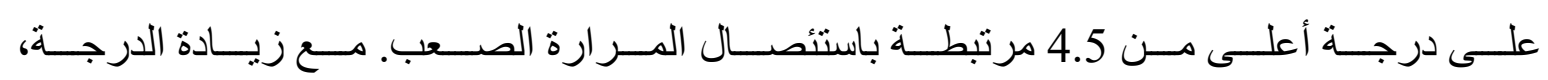

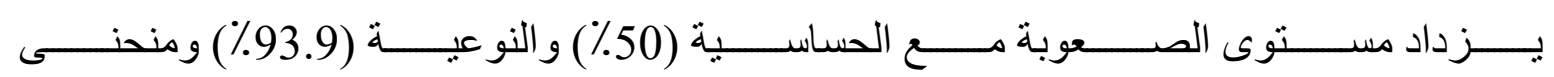
$0.003=$ كبيرة P P = (0.007)

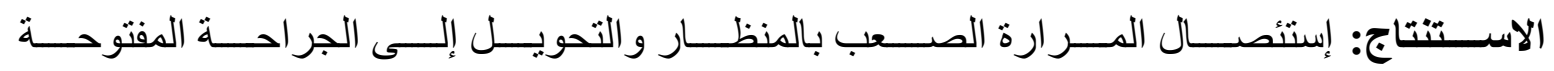

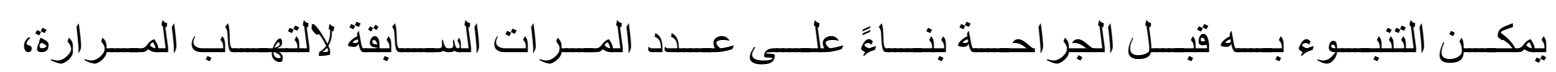

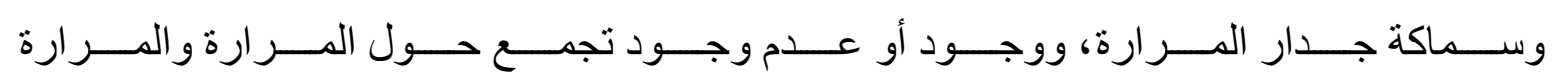
الملموسة أو الحصو ات المدفونة في العنق.

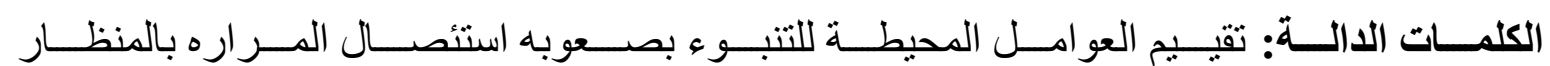
الجر احي. 